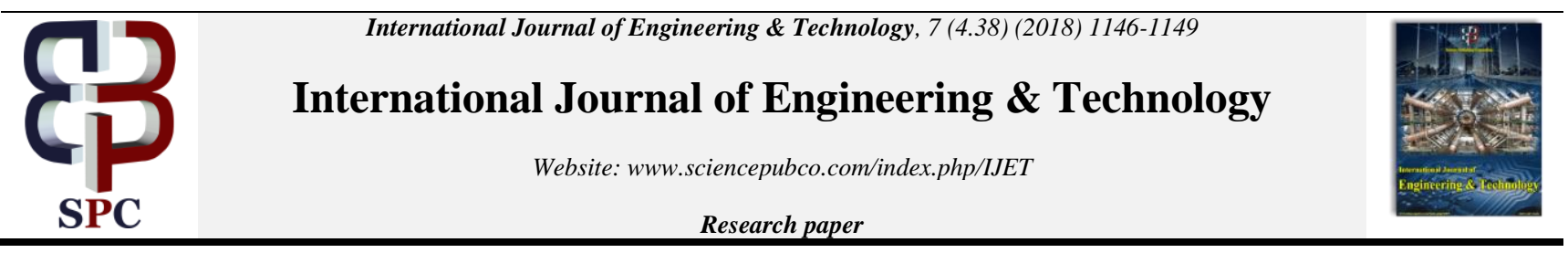

\title{
Automated Classification of Agricultural Lands Using GIS and NES
}

\author{
V. K. Kalichkin ${ }^{1 *}$, A. I. Pavlova ${ }^{1}$, A. F. Petrov², V. A. Smolyakov ${ }^{2}$ \\ ${ }^{1}$ Siberian Federal Scientific Center of Agrobiotechnology RAS, Russia \\ ${ }^{2}$ Novosibirsk State Agrarian University, Russia \\ *Corresponding authorE-mail: kalichkinv@yandex.ru
}

\begin{abstract}
The article proposes the methodology for the automated classification of uplands using Geographic Information System (GIS) and Neural Expert System (NES). Quantitative indicators of topography are used as the basis of the proposed classification. A database consisting of topographic, soil, and land use maps was created using ArcGIS 10 geographic information system. A topologically correct digital elevation model (DEM) was created by the ANUDEM interpolation method. The DEM contains the following maps: hypsometric, steepness and slopes exposure, plan, profile, common curvature of the ground surface, and cumulative runoff maps. The boundaries of elementary surfaces (ES), which are homogeneous morphological formations, are established. Parameters characterizing the Stream Power Index (SPI) are taken into account. The essence of the proposed classification consists in attributing of ES to a certain group of lands based on aggregate of features. To do this, partial scales were created, containing indicators of topography, soil cover, land drainage conditions, as well as the degree of erosion development. The authors formed knowledge base for traning the NES using GIS database and partial scales of estimates. Teaching of neural network was carried out. The classification and topology of land was carried out by means of the NES. The uplands are distributed in flat and slightly convex areas. They are characterized by the following indicators: the curvature of the ground surface: plan curvature $(0-0.03)$, profile curvature $(0-0.15)$, common curvature $(0-0.22)$; slope angles (less than $1.5^{\circ}$ ); horizontal dissection in elevation (less than $0.5 \mathrm{~km} / \mathrm{km}^{2}$ ), vertical dissection (less than $5 \mathrm{~m}$ ); and SPI (from -13.80 to -6.47). Electronic map of uplands of LLC «Salair» land-use area was created in the ArcGIS 10 environment.
\end{abstract}

Keywords: GIS, NES, Topography, Agricultural Land, Classification, Elementary Surfaces.

\section{Introduction}

The classification of agricultural lands is a necessary step in the design of agricultural systems [1]. The classification is closely related to the agroecological assessment and involves the analysis of land by the most significant natural factors affecting the nature of their use in agricultural production. The system of agroecological assessment and classification of lands is implemented at different levels, namely regional and local ones. A variety of data are involved for its implementation, such as topographic maps and pedological charts, natural zoning materials, statistical sources, etc. To date, the classification or categorization of a particular area of the ground surface to a certain agro-ecological group of lands has been carried out by an expert, usually manually according to a declarative model based on the qualitative and partly quantitative characteristics of this area. At the same time, there is an urgent need to make this process formalized with the greatest possible automation. In particular, for the lands' classification and categorization of the so-called uplands, in our opinion, it is possible to use morphometric parameters of the topography.

The role of topography in the formation of agroecological conditions of agricultural lands is generally recognized. Changes of topography in space and time have an impact on agro-climatic conditions, surface water runoff, erosion processes, etc. [2,3]. The development of contemporary information processing technologies makes it possible to formalize topographic description process, to present this information in a form convenient for simulation. One of the possible solutions is the use of quantitative characteristics of the topography [4-6]. The most promising research is associated with obtaining geomorphometric indicators through the numerical simulation. In the arsenal of contemporary methods of data analysis, there are also fuzzy logic [7] and artificial neural networks [8-10].

The purpose of the present research is to develop methodological bases of the automated method of uplands' classification using the analysis and simulation procedures of geomorphometric topography indicators by integrating the GIS and NES.

\section{Methods}

The research object was the LLC «Salair» land-use area of Maslyaninsky District of the Novosibirsk Region.

Land classification consisted of the following interrelated stages:

- conducting preliminary thematic processing of space images to allocate the elementary surfaces (ES) in the study area;

- forming the GIS territory by integrating different materials in the form of raster and vector layers;

- collecting and systematizing scientific research to form assessment scales;

- developing cartographic knowledge base;

- integrating the knowledge about the territory and performing computational experiments aimed at training the NES;

- using of trained NES for land classification and displaying results; 
- preparing electronic maps of the uplands with associated databases.

Recognition of space images was carried out by visual and automatic decoding methods using the ENVI software. This approach allowed constructing a map of ES in the GIS vector format. The results of decoding allowed studying the structure of landscapes and soil cover, and determining the scale of agricultural development of the territory.

By means of full-featured ArcGIS 10, the GIS database was created, which included topographic, soil, and land use maps. The characteristics of topography (geomorphometric parameters), soil cover, depth to groundwater, and the degree of soil erosion were used as the classification criteria of uplands. The listed features and the limits of their changes are structured in the database of partial scales of assessments by means of Microsoft Access 2013 data base management system [11].

Digital elevation model (DEM) was created on the basis of topographic map using ANUDEM method [12]. In the course of simulation, GRID model cell size was chosen to be $5 \mathrm{~m}$ based on research work [13]. This allowed calculating the quantitative parameters of topography and creating through the instrumentality of numerical simulation morphometric maps of slopes' steepness, horizontal and vertical dissection, plan, profile, and common curvature of the ground surface, as well as the SPI (Stream Power Index).

Morphometric maps of topography were used to determine the boundaries of ES, which represented morphologically homogeneous formations, bounded by faces and bends in topography $[14,15]$.

The classification and topology of the lands was carried out using neural networks. For training of neural network with the teacher, the knowledge base was created consisting of ES set. An individual contour of the ES was evaluated by its belonging to a group of lands by comparing the attribute data of the ES and database assessment scales. To train a multilayer neural network, we used a gradient algorithm of error back-propagation with a momentum term implemented using the Matlab 2014 software complex.

\section{Results and discussion}

Feature selection for classification of uplands is closely linked with their definition. Uplands are understood as the lands, which are common on the plains drained areas. These lands are characterized by developed automorphic zonal soils with limited redistribution of precipitation and other agro-climatic resources in relation to the average annual characteristics [1]. By default, it is assumed that these lands are not subject to water erosion.

In this regard, it was decided to allocate areas with varying degrees of water erosion. To do this, we used data on the soil cover of the territory and topography indicators, namely steepness of the slopes and the SPI. In the literature, the SPI is called "Stream Power Index" [16], or "Linear Erosion Power Index" [17] This index characterizes the accumulation of sedimentary rocks, the potential for erosion [2, 3], and is used to assess erosion processes [18, 19]. The exception of lands subject to erosion allowed us to more objectively identify uplands in the area under study.

A general analysis of the hypsometric information of LLC «Salair» land-use area showed that the absolute elevations amounted on average to $400 \mathrm{~m}$, depth of the erosion bases was 20$40 \mathrm{~m}$, while in some cases it was more than $50 \mathrm{~m}$. The lower areas of the farm land belonged to the river valleys and ravines, as well as to Yelban floodplain. A significant part of the territory (about $88 \%$ ) was occupied by the slope lands of different steepness. At that, very flat and gentle slopes together were distributed over $35 \%$ of the territory, while steep and very steep lands occurred in $5.9 \%$ of the territory. The average value of slope steepness was $3.9^{\circ}$
Statistical analysis of the SPI map showed that their values fell within the range from -13.81 to 12.93 ; the average value was 0.48 , while the standard deviation was 2.57 . Building a map of SPI classes was conducted using the natural intervals method (Jenks, 1967). The following classes were allocated for the LLC "Salair" land-use area: lands with no erosion (index values varied from -13.80 to -6.47 ), lands with low potential for erosion development (from -6.46 to -1.54 ), lands with moderate potential (from -1.54 to 0.24 ), lands with high potential (from 0.25 to 2.76), and lands with very high development potential for erosion (from 2.76 to 12.93 ).

Based on the analysis of the electronic slope maps consisting of various layers, SPI grades, and soil cover, the following erosion lands were allocated:

slightly erosive lands with the slope steepness from 1.5 to $3^{\circ}$, weakly washed-off soils and low potential for erosion;

moderately erosive lands with the slope steepness from 3 to $5^{\circ}$, moderately washed-off soils and moderate potential for erosion; strongly erosive lands with the slope steepness from 5 to $8^{\circ}$ with strongly washed-off soils and high potential for erosion;

extremely strongly erosive lands with the slope steepness more than $8^{\circ}$, strongly washed-off and cumulic soils, and very high potential for erosion.

The values of the plan curvature varied from -7.9978 to 11.6838 , the mean value was -0.0029 , while the standard deviation was 0.1473 . The plan curvature characterizes the change in the gradient along a given direction, and describes the first accumulation mechanism associated with the ability of the flow to change as it moves along the ground surface. The plan curvature determines the convergence and divergence of the substance flow $[2,3]$.

Profile curvature values ranged from -9.798 to 8.839 with an average of 0.003 and a standard deviation of 0.188 . Profile curvature serves a measure of the relative deceleration of flows moving along the ground surface under gravity (the second mechanism of accumulation). Profile curvature affects the flow acceleration or deceleration, i.e. erosion and deposition of precipitation. In concave areas, the velocity of surface and subsurface runoff slows down, while in convex areas it accelerates. Profile curvature is used to determine the location of the accumulation zones for the concave sections, and of zones of its demolition - for the convex ones.

The common curvature varied from -14.663 to 21.482 , the average was -0.066 , and the standard deviation was 0.152 . The common curvature serves a cumulative measure of the ground surface curvature characterizing both mechanisms of accumulation [21, 22].

Thus, the values of the plan, profile, and common curvatures vary within significant limits. The division of the topography into convex, concave, and flat surfaces is performed based on the obtained curvature maps. Convex surfaces are characterized by positive curvature, concave surfaces - by negative one, while for flat surfaces curvature is zero (Table 1 ).

Table 1: A fragment of partial scales to assess the plan, profile, and common curvature of the ground surface

\begin{tabular}{|l|l|l|}
\hline Indicator & Gradations & Surface shape \\
\hline \multirow{3}{*}{$\begin{array}{l}\text { Plan curvature } \\
C_{\text {plan }}\end{array}$} & $\mathrm{C}_{\text {plan }}<0$ & Convex in plan \\
\cline { 2 - 3 } & $\mathrm{C}_{\text {plan }}>0$ & Concave in plan \\
\cline { 2 - 3 } $\begin{array}{l}\text { Profile curvature } \\
\mathrm{C}_{\text {prof }}\end{array}$ & $\mathrm{C}_{\text {plan }}=0$ & Flat surfaces \\
\hline \multirow{3}{*}{$\begin{array}{c}\text { Common curvature } \\
\mathrm{C}\end{array}$} & $\mathrm{C}_{\text {prof }}>0$ & Convex in profile \\
\cline { 2 - 3 } & $\mathrm{C}_{\text {prof }}<0$ & Concave in profile \\
\cline { 2 - 3 } & $\mathrm{C}_{\text {prof }}=0$ & Flat \\
\cline { 2 - 3 } & $\mathrm{C}<0$ & Convex \\
\cline { 2 - 3 } & $\mathrm{C}>0$ & Concave \\
\cline { 2 - 3 } & $\mathrm{C}=0$ & Flat \\
\hline
\end{tabular}

By dint of GIS, we allocated ES by the characteristic points and structural lines of the topography. Characteristic points of the topography were the greatest elevations and topographic lows, as 
well as the tops of the saddles. The position of the structural lines of topography has been specified in the course of overlay analysis of morphometric topography maps.

The ES of various steepness and curvature were allocated within the working areas of the arable land. In Fig. 1, the convex ES are shown in a light tone, while the concave ones are shown in a darker tone, the separation line passes along the zero-curvature isolines. Joint analysis of the profile and plan curvature maps allows indicating the distribution of elementary forms (Fig. 1b). Overlaying the slope angles' map contributes to a more detailed classification (Fig. 1c).
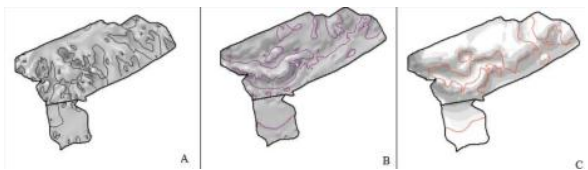

Fig. 1: The results of the ES allocation within the boundaries of arable land ( $\mathrm{a}$ - based on the plan curvature; $\mathrm{b}$ - based on the profile curvature; $\mathrm{c}$ based on the plan curvature, profile curvature, and slope angles).

In consequence of the joint analysis of plan and profile curvature maps and the slope angles' map, various types of ES were established in the area under study, namely flat surfaces, convex surfaces with different slope angles, and concave surfaces. At the same time, flat surfaces were divided into surfaces related to floodplains of rivers, ravines, and beams, as well as surfaces confined to watersheds.

ES are characterized by attribute data, which include information about the morphometric parameters of the topography, soils, depth to groundwater, and the degree of erosion. Based on the information about the ES and database of partial scales, a knowledge base had been formed for training multilayer neural network in PC Matlab 2014, which included 1200 input data. The NES knowledge base was created in relation to the ES according to the following criteria: elevation above sea level $\left(\mathrm{P}_{1}\right)$, steepness slope $\left(\mathrm{P}_{2}\right)$, the depth of the erosion bases $\left(\mathrm{P}_{3}\right)$, plan curvature $\left(\mathrm{P}_{4}\right)$, profile curvature $\left(\mathrm{P}_{5}\right)$, and the common curvature of the surface $\left(\mathrm{P}_{6}\right)$, depth to groundwater $\left(\mathrm{P}_{7}\right)$, cumulative land runoff $\left(\mathrm{P}_{8}\right)$, and erodibility $\left(\mathrm{P}_{9}\right)$.

According to the chosen architecture, the multilayer network contained an input, two hidden, and one output layer. Evaluation of the neural network training quality was carried out through the calculation of the MSE (Mean Square Error) and RMSE (Root Mean Square Error) coefficients, which amounted to 0.92 and 0.96, respectively. Trained neural network has been used to classify the uplands and the creation of electronic map.

The uplands were allocated on the elevated flat and slightly convex areas with slopes of topography less than $1.5^{\circ}$, depth of the erosion bases up to $5 \mathrm{~m}$, and horizontal dissection of topography less than $0.5 \mathrm{~km} / \mathrm{km}^{2}$ (Fig. 2).

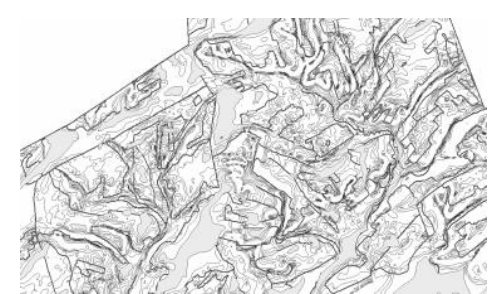

Fig. 2: The electronic map of the uplands of the LLC «Salair» land-use area (scale 1:50 000)

boundaries of arable plots uplands contours

The plan curvature of the uplands ranges from 0 to 0.03 , profile curvature ranges from 0 to 0.15 , and common curvature varies from 0 to 0.22 . Under these geomorphological conditions, the erosion processes are manifested to a small extent or do not exist at all. The SPI is changed from minus 13.80 to minus 6.47 .
In general, uplands occupy a very small part of the agricultural economy (about 5\%) and are intensively used in agricultural production as arable land.

The uplands are widespread in dark gray, gray, and light-gray forest podzolic medium and shallow soils of medium loam and heavy loam granulometric composition at the depth to groundwater more than $6 \mathrm{~m}$. Dark-gray forest medium (with ballbonitet of the soil equal to 82) and grey forest medium (ballbonitet equal to 72) soils are the most fertile.

\section{Conclusion}

The use of the NES for agricultural lands' classification is based on the ES selection and mapping. The contours of the ES form an irregular network of habitats, which is filled with semantic description using ArGIS 10 Geographic Information System. The structure and content of DEM layers are used to select training examples of the NES. This allows applying the methods of neural network data analysis, overcoming the difficulties associated with the processing of large amounts of raw data, their heterogeneity, and the lack of clear classification criteria.

The use of the error back-propagation with a momentum term as a training algorithm allows speeding up the training process and avoiding "local" minima of the error function. However, the practical implementation of the algorithm requires the selection of training rate and momentum terms. In this regard, the PC Matlab 2014 was used to train the neural network. In general, using the GIS and NES for the classification of uplands is iterative, and allows the researcher to obtain information about the spatial location of the lands on the map.

The uplands of LLC «Salair» land-use area are widespread on flat and slightly convex areas, and are characterized by the following geomorphometric indicators: the curvature of the ground surface: plan curvature $(0-0.03)$, profile curvature $(0-0.15)$, common curvature $(0-0.22)$; slope angles (less than $\left.1.5^{\circ}\right)$; horizontal dissection in elevation (less than $0.5 \mathrm{~km} / \mathrm{km}^{2}$ ), vertical dissection (less than $5 \mathrm{~m}$ ); and the SPI (minus 13.80 - minus 6.47). The uplands are widespread in dark gray, gray, and light-gray forest podzolic medium and shallow soils of medium loam and heavy loam granulometric composition.

\section{Booknotes}

1. Geographic Information System

2. Neural Expert System

\section{References}

[1] Kiryushin VI, Ivanov AL (2005), Agroehkologicheskaya ocenka zemel', proektirovanie adaptivno-landshaftnyh sistem zemledeliya agrotekhnologij. Metod. ruk-vo [Agroecological assessment of lands, design of adaptive landscape systems of arable farming and agricultural technologies]. Moscow, Russia: Federal State Institution of Science "Rosinformagrotekh".

[2] Tanasienko AA (2003), Specifika ehrozii pochv v Sibiri [Specificity of soil erosion in Siberia]. Novosibirsk, Russia: Publishing House of SB RAS.

[3] Reingard YaR (2009), Degradaciya pochv ehkosistem yuga Zapadnoj Sibiri [Soil degradation of ecosystems in the south of Western Siberia]. Omsk, Russia.

[4] Wilson JP (2000), Topography analysis: Principles and applications.

[5] Hengl T, Hannes I (2009), Geomorphometry: Concepts, software, applications. Reuter

[6] Florunsky I (2012), Digital topography analysis in soil science and geology. Elselver.

[7] Pegat A (2013), Fuzzy modeling and control. Moscow, Russia: Binom, Knowledge Laboratory. 
[8] Barsky AB (2004), Nejronnye seti: raspoznavanie, upravlenie, prinyatie reshenij [Neural networks: Recognition, control, and decision-making]. Moscow, Russia: Finance and Statistics.

[9] Rutkovsky L (2010), Metody i tekhnologii iskusstvennogo intellekta [Methods and technologies of artificial intelligence]. Moscow, Russia: Hotline-Telecom.

[10] Redko VG (2011), Ehvolyuciya, nejronnye seti, intellekt modeli i koncepciya ehvolyucionnoj kibernetiki [Evolution, neural networks, intelligence models, and the concept of evolutionary cybernetics]. Moscow, Russia: Librokom.

[11] Pavlova AI, Kalichkin VK (2016), Ispol'zovanie geomorfometricheskogo analiza rel'efa pri sozdanii baz dannyh sel'skohozyajstvennyh zemel' [Use of geomorphometric topography analysis in the creation of agricultural lands databases]. Siberian Bulletin of Agricultural Sciences, 5, 5-12.

[12] Hutchinson MF (1989), A new method for gridding elevation and stream line data with automatic removal of pits. Journal of Hydrology, 106, 211-232.

[13] Hegl T (2006), Hiding the right pixel size. Computers and Geosciences, 32(9), 1283-1298.

[14] Lastochkin AN (1991), Morfologicheskaya osnova sistematiki i kartografirovaniya kontroliruemyh rel'efom komponentov landshafta [Morphological base of taxonomy and mapping of landscape components controlled by the topography]. Bulletin of the USSR Academy of Sciences, Geogr. Ser., 3, 7-18.

[15] Lastochkin AN (2002), Sistemno-morfologicheskoe osnovanie nauk o Zemle (geotopologiya, strukturnaya geografiya i obshchaya teoriya geosistem) [System-morphological basis of Earth sciences (geotophology, structural geography, and the general theory of geosystems)]. St.Petersburg, Russia: Publishing House of St. Petersburg State University.

[16] Omelko AM, Yakovleva AN (n. d.), Cozdanie kart potencial'noj rastitel'nosti s ispol'zovaniem generalizovannyh additivnyh modelej [Creation of potential vegetation maps using generalized additive models]. http://www.biosoil.ru/files/00010291.pdf.

[17] Glotov AA (2013), Primenenie dannyh o rel'efe dlya ehffektivnogo ispol'zovaniya sel'skohozyajstvennyh zemel' [Application of topography data for effective use of agricultural lands]. Geoprofi, $4,20-22$.

[18] Wisconsin Department of Natural Resources. (2016). Erosion Vulnerability. Assessment for Agricultural Lands (EVAAL). https://dnr.wi.gov/topic/nonpoint/evaal.html.

[19] Danielson T (n. d.), Utilizing a high resolution digital elevation model (DEM) to develop a stream power index (SPI) for the Gilmore Creek Watershed in Winona County, Minnesota. http://www.gis.smumn.edu/GradProjects/DanielsonT.pdf.

[20] Jenks GF (1967), The data model concept in statistical mapping. International Yearbook of Cartography, 7, 186-190.

[21] Zeverbergen LW, Thorne CR (1987), Quantitative analysis of land surface topography. Earth Surface Processes and Landforms, 12, 47-56.

[22] Osnovnye geomorfometricheskie parametry: teoriya [Basic geomorphometric parameters: Theory]. (2015). 